nificant contributions to the war effort, favorable experience with this financing has encouraged banks to participate further in financing by assignment of accounts receivable. The 1951 Amendment to the Assignment of Claims Act leaves a security device that is essentially sound. Certain areas of legal uncertainty remain, but scarcely such as interfere with the normal commercial calculation of risk.

\title{
FEDERAL AREAS: THE CONFUSION OF A JURISDICTIONAL-GEOGRAPHICAL DICHOTOMY
}

Posing the Problem.-X was convicted of murder under a state criminal statute. On appeal conviction was reversed for lack of jurisdiction because the crime was committed on a military reservation under the exclusive jurisdiction of the federal government. ${ }^{1}$ Subsequently $\mathrm{X}$ was indicted under a federal statute. The federal court refused jurisdiction after deciding that the land in question was in reality under the jurisdiction of the state. ${ }^{2}$ Although $\mathrm{X}$ went free, the sovereignty of each government remained unimpaired. While this is an extreme case it illustrates the fact that difficulties arise because of the existence of federal areas within the geographic boundaries of the states. Moreover, their impact today is greater than ever before.

Historically, the public domain comprised those lands beyond the boundaries of the original states, but as new states were formed out of these areas the federal government reserved certain portions within state borders. Besides these "public lands" there are so-called "acquired lands" which have been secured from the states or private owners by purchase, gift or condemnation. At the present time there are approximately $455,000,000$ acres under federal ownership which is $23 \%$ of the total land area of the continental United States. ${ }^{3}$ About $90 \%$ of this land is "public domain" and $10 \%$ is "acquired." 4

Vast amounts of the public lands are reserved for forestry, reclamation, conservation, etc. However, of particular interest here are the lands which have been reserved for military projects or such purposes as defense housing $^{5}$ or atomic energy development, ${ }^{\bullet}$ all of which require the presence of

1. State v. Tully, 31 Mont. 365, 78 Pac. 760 (1904).

2. United States v. Tully, 140 Fed. 899 (9th Cir. 1905).

3. H.R. REP. No. 3116, 81st Cong., 2d Sess. 2 (1949).

4. Graphic Notes on the Pubuic Domain 2 (Dep't of the Interior, Bureau of Land Management 1950).

5. California ceded jurisdiction to the United States over land acquired for housing by Cal. Laws 1943 , c. $96, \$ 1$.

6. For a full discussion of the acquisition of land for and jurisdiction over the atomic energy project at Los Alamos, New Mexico see Arledge v. Mabry, 52 N.M. 66,201 P.2d 782 (1949). 
numerous people as residents of federal areas. The steady expansion of federal activities, especially in the last twenty years, has resulted in the acquisition of increasingly large amounts of land for such purposes. Consequently the problems raised by the growing complexity of this federalstate relationship are affecting a constantly increasing proportion of the population, civilian as well as military. ${ }^{7}$ It is the purpose here to point out these problems of the federal areas and evaluate the methods by which they may be overcome.

Acquisition of land and jurisdiction.-The Constitution provides for only two relationships of the federal government to land. One is the regulation of the territories held in trust for the states. ${ }^{8}$ The other is the power of Congress to exercise exclusive legislation over:

"such District (not exceeding ten Miles square) as may, by Cession
of particular States, and the Acceptance of Congress, become the Seat
of the Government of the United States, and to exercise like Authority
over all Places purchased by the Consent of the Legislature of the
State in which the Same shall be, for the erection of Forts, Magazines,
Arsenals, dock-Yards, and other needful Buildings;-" 9

The latter description was originally contemplated as referring only to places necessary for military installations. ${ }^{10}$ However, the courts have construed "other needful buildings" to mean whatever structures are found necessary to the performance of the functions of the federal government. Thus interpreted this phrase has been the authority for purchasing sites for

7. The following table shows the distribution of land areas under federal jurisdiction among some of the major agencies in 1949:

\section{Agency}

Dep't of the Interior

Dep't of Agriculture

Dep't of the Air Force

Dep't of the Army*

Dep't of the Navy

T.V.A.

Atomic Energy Comm'n.
Acreage
$262,155,710$
$167,656,498$
$11,738,806$
$9,020,424$
$2,345,496$
891,196
487,519

* Military lands include $3,409,066$ acres acquired by purchase or condemnation and $3,130,533$ acres acquired by transfer from other Federal agencies. Note 3 supra at 3 and 4 . It is estimated that "acquired lands" for civilian purposes doubled from the time of the recovery and conservation activities of the early New Deal to the time of World War II. Likewise, war agencies increased their holdings of "acquired lands" many fold prior to and during the war and held about 10,000,000 such acres when the war ended. Note 4 supra at 3 . The Bureau of the Census has compiled no figures for the population of such federal areas. Communication to the UNIversity of Pennsyivania Law Review from C. E. Batschelet, Chief, Geography Division, Bureau of the Census, dated April 11, 1952, on file in Biddle Law Library, University of Pennsylvania.

8. U.S. Const. Art. IV, $\$ 3$, cl. 2.

9. U.S. Const. Art. I, \$ 8, cl. 17.

10. The Feneralist, No. 43 at 279-280 (Mod. Lib. ed. 1943) ; 5 Elliot's DeBATES $510-512$ (1845). For a discussion of the history of the adoption of clause 17 see Patterson, The Relation of the Federal Government to the Territories and the States in Landholding, 28 Texas L. REv. 43, 57-62 (1949). 
post office buildings, ${ }^{11}$ court houses, ${ }^{12}$ soldiers' homes, ${ }^{13}$ hotels ${ }^{14}$ and other buildings. For almost a century the federal government acquired what land it needed by the method specified by the Constitution: purchase with the consent of the states. Such consent usually reserved to the states the right to serve civil and criminal process within the area. ${ }^{15}$ This reservation was upheld as a precaution against such lands becoming asylums for fugitives from justice, ${ }^{10}$ but any qualifications beyond this were deemed incompatible with exclusive federal jurisdiction. ${ }^{17}$ Then in Kohl v. United States ${ }^{1 s}$ the Supreme Court marked the way for another method of acquisition by holding that "the right of eminent domain ... . [in the federal government] . . . may be exercised within the states, so far as is necessary to the enjoyment of the powers conferred upon it by the Constitution." 19

The outstanding decision relating to jurisdiction over federal lands was Fort Leavenworth R.R. v. Lozee. ${ }^{20}$ The Court, per Mr. Justice Field, held that when land is acquired other than by purchase with consent, the states, in ceding jurisdiction to the United States, can reserve such powers as are not inconsistent with the effective use of the property for the purpose intended. ${ }^{21}$ The two latest developments in this area have been decisions holding that a state may reserve powers other than the right to serve process even over lands purchased with consent ${ }^{22}$ and may cede jurisdiction over lands acquired for a purpose not specified in Art. I, $\S 8$ of the Constitution. ${ }^{23}$ Of course, where no jurisdiction has vested in the United States its status is merely that of a proprietor. ${ }^{24}$

\section{The Federal-State Relationship}

Exclusive Federal Jurisdiction.-Exclusive jurisdiction over federal areas necessarily creates problems affecting the inhabitants thereof. They are not residents of the state. ${ }^{25}$ They may not be entitled to the benefits

11. Battle v. United States, 209 U.S. 36 (1907).

12. State v. Mack, 23 Nev. 359,47 Pac. 763 (1897).

13. State v. Willett, 117 Tenn. 334, 97 S.W. 302 (1906).

14. Arlington Hotel Co. v. Fant, 278 U.S. 439 (1929).

15. Rogers v. Squier, 157 F.2d 948 (9th Cir. 1946); State v. Mack, 23 Nev. 359, 47 Pac. 763 (1897) ; In re Ladd, 74 Fed. 31 (C.C.D. Neb. 1896).

16. Fort Leavenworth R.R. v. Lowe, 114 U.S. 525 (1885).

17. Opinion of the Justices, 1 Metc. 580 (Mass. 1841).

18. 91 U.S. 367 (1875).

19. Id. at 372 .

20. 114 U.S. 525 (1885).

21. The jurisdiction reserved was to "serve civil or criminal process" and to "tax railroad, bridge, and other corporations, their franchises and property, on said Reservation." Kansas Laws 1875, p. 95; incorporated by reference, KAN. GEN. Stat. ANN. c. $27, \$ 104$ (1935).

22. James v. Dravo Contracting Co., 302 U.S. 134 (1937)

23. Collins v. Yosemite Park \& Curry Co., 304 U.S. 518 (1938) (jurisdiction ceded over land to be used for a national park).

24. 2 Story, Constitution $\$ \S 1214-1235$ (5th ed. 1891); Fort Leavenworth R.R. v. Lowe, supra note 15 at 527.

25. Bank of Phoebuş v. Byrum, 110 Va. 708, 67 S.E. 349 (1910). 
of state laws ${ }^{26}$ and conversely may not be subject to its penalties and taxes. ${ }^{27}$

Such a situation is bound to create difficulties for the states. For example, lacking the power of taxation over such an area, a state is deprived of valuable sources of revenue. Not only are federal instrumentalities immune, $^{28}$ but state excise, ${ }^{29}$ capitation ${ }^{30}$ and personal property taxes ${ }^{\mathbf{3 1}}$ may be of no effect within the area. In the case of inheritance taxes the state has the burden of proving that the deceased was a state resident. ${ }^{\mathbf{2}}$ A corporation acting solely within a federal area cannot be taxed for the privilege of doing business within the state. ${ }^{33}$ Furthermore, states have no jurisdiction over crimes committed within the area. ${ }^{34}$ Regulatory legislation such as licensing requirements ${ }^{35}$ or municipal building ordinances ${ }^{36}$ may be inapplicable; nor can a state confiscate liquor in transit to a military post, though its importation is forbidden by state law. ${ }^{37}$

Many anomalous situations arise in the procedural aspects of litigation. The property of a resident of a federal enclave may be subject to attachment as that of a non-resident though geographically he is within the state; ${ }^{38}$ and for the purpose of serving process upon a corporation which is on federal land, such corporation is deemed not to be doing business within the county. ${ }^{39}$ Likewise, if a breach of contract action arises on a federal area the state court has no jurisdiction. ${ }^{40}$ However, where Congress

26. See note 17 supra.

27. Pundt v. Pendleton, 167 Fed. 997 (N.D. Ga. 1909).

28. Falls City Brewing Co. v. Reeves, 40 F. Supp. 35 (W.D. Ky. 1941) ; Van Brocklin v. Tennessee, 117 U.S. 151 (1886); McCulloch v. Maryland, 4 Wheat. sิ16 (U.S. 1819).

29. State v. Blair, 328 Ala. 377, 191 So. 237 (1939).

30. United States v. Naylon, 3 Alaska 88 (1906).

31. Surplus Trading Co. v. Cook, 281 U.S. 647 (1929).

32. In re Grant's Estate, 83 Misc. 257, 144 N.Y. Supp. 567 (1913).

33. Winston Bros. v. State Tax Commission, 156 Ore. 505, 62 P.2d 7 (1937).

34. Rogers v. Squier, 157 F.2d 948 (9th Cir. 1946) ; People v. Hillman, 246 N.Y. 467, 159 N.E. 400 (1927) ; Western Union Telegraph Co. v. Chiles, 214 U.S. 274 (1909) ; Battle v. United States, 209 U.S. 36 (1908); State v Mack, 23 Nev. 359, 47 Pac. 763 (1897). But cf. In re Kelly, 71 Fed. 545 (C.C.E.D. Wis. 1895) (where United States had not declared necessity for exclusive jurisdiction, land purchased for a purpose not within Art. I, $\$ \&$, cl. 17 of the Constitution creates only concurrent jurisdiction).

35. Peterson v. United States, 191 F.2d 154 (9th Cir. 1951) (United States has exclusive jurisdiction over the regulation of the sale of liquor by private persons owning land within a national park); Lynch v. Hammock, 204 Ark. 911, 165 S.W.2d 369 (1942) (physician practicing exclusively on federal area not subject to Arkansas licensing requirements); Collins v. Yosemite Park \& Curry Co., 304 U.S. 518 (1938) (licensing provisions of California Alcoholic Beverage Control Act unenforceable in Yosemite National Park).

36. United States v. City of Chester, 144 F.2d 415 (3d Cir. 1944). But cf. Stewart v. Sadrakula, 309 U.S. 94 (1940) (New York Labor Law requiring planking over steel beams applied to contractor constructing post office building for the federal government).

37. Johnson v. Yellow Cab Transit Co., 321 U.S. 383 (1944).

38. Bank of Phoebus v. Byrum, 110 Va. 708, 67 S.E. 349 (1910).

39. Neidig v. Century Sprinkler Corp., 60 Dauph. 585 (Pa. C.P. 1950).

40. Hercules Powder Co. v. Ruben, 188 Va. 694, 51 S.E.2d 149 (1949). 
has approved the application of state laws to a federal area it remains the function of the state court to construe them and an action cannot be removed to a federal court as one arising under the laws of the United States. ${ }^{41}$

A more technical but equally important question arises in connection with the recording of vital statistics. The federal government has no bureau of vital statistics for recording births and deaths occurring on federal land. Confusion in this area can be harmful to the individual in view of the evidentiary value of such documents. As to federal military reservations, if jurisdiction has not been ceded births and deaths must be reported to the local authorities. Where there is exclusive federal jurisdiction the procedure is questionable. There are no Army Regulations or federal laws which provide for recording such statistics. ${ }^{42}$ However, state procedure is usually followed by the Army as a matter of policy. ${ }^{43}$ Thus, such statistics for Valley Forge General Hospital are recorded in Chester County, Pennsylvania, as if the hospital were in fact within the jurisdiction of the county.44 A child who is born on a military reservation and whose father is in the service becomes a citizen of the state of which his father is a citizen, for a soldier does not lose his citizenship or residency in his home state during his service in the army. ${ }^{45}$ However, the citizenship of a child born to civilians whose only residence is a federal reservation would not benefit by this fact and there seems to be no answer to his plight. Thus, while it may be an easy matter to say that $X$ area is under exclusive federal jurisdiction, the ramifications of this fact are less easily pigeonholed.

Continued Force of State Lawes.-The greatest difficulty arising from the cession of exclusive jurisdiction to the United States is that there is no complete body of federal law to supplant the state laws from whose reach the areas are at least theoretically removed. Yet it should not be expected that the residents of such areas are to live in a legal vacuum. One attempted solution to this problem was the application of the international law principle that the laws of the old sovereign, not incompatible with those of the new, remain in force until changed or abrogated by the new government.

41. Misner v. Cleveland Wrecking Co. of Cincinnati, 25 F. Supp. 763 (W.D. Mo. 1938).

42. Communication to the University of Pennsylvania Law Review from Capt. Loren J. Bullock, Assistant Post Judge Advocate, Valley Forge Army Hospital, Phoenixville, Penna. (May 12, 1952) on file in Biddle Law Library, University of Pennsylvania Law School.

43. Ibid.; Communication to the University of Pennsylvania Law Review from Col. Devlin, Medical Director, Frankford Arsena1, Phila., Penna. (1952) on file in the Biddle Law Library, University of Pennsylvania Law School. The records kept on such reservations are of a private nature rather than taking the place of the public records of a political subdivision.

44. See note 42 supra.

45. Knowiton v. Knowlton, 155 I11. 158, 39 N.E. 595 (1895); See also note 43 supra. 
This doctrine was discussed at some length in Chicago, R.I. \& Pac. Ry. v. McGlinn, ${ }^{46}$ where a suit was brought against the Railway Company for the value of a cow killed by a train within the borders of Fort Leavenworth Military Reservation. A Kansas statute made the railroad liable for the value of cattle killed by operation of the railway. The defendant maintained that this law of Kansas became inoperative within the reservation when jurisdiction was ceded to the United States. The Court held that the international law principle applied and that:

"The government of the State of Kansas extended over the Reservation, and its legislation was operative therein, except so far as the use of the land as an instrumentality of the general government may have excepted it from such legislation." 47

The same reasoning was applied by a Tennessee court in recognizing the appointee of the state court as administrator of the estate of a decedent who had been a resident of a federal soldiers' home. The amount of the estate was insufficient to bring it within the jurisdiction of the federal courts and there is no federal probate jurisdiction. The court felt that private rights must be enforced under state laws which, it was held, continued in force after the cession of jurisdiction. ${ }^{48}$

The difficulty with this reasoning is that the state laws in force at the time of cession continue in effect indefinitely. ${ }^{49}$ Neither a subsequent repeal by the state ${ }^{50}$ nor the adoption of a new law has any effect in the federal area. ${ }^{51}$ This means that where federal residents are dependent on state law they may find themselves hampered by outmoded statutes and deprived of such innovations as have been made to keep step with changing economic and social needs. A notable example is that of an innkeeper on a federal reservation who was held liable as an insurer although the state law had been modernized so that his fellow innkeepers in the state were liable only for negligence. ${ }^{52}$ Such an application of obsolescent law produces unrealistic results, since, if state law is to govern, it should effect the same legal relationships for all persons subject to it.

A Jurisdictional Void.-It is quite possible that there may be instances where neither state nor federal law is applicable to an area. This anomalous situation usually arises in a field of law concerning which (1) there is no federal legislation and (2) the particular state statute is inapplicable. An example is the field of domestic relations, which belongs exclusively to the law of the states ${ }^{53}$ and in which, for certain purposes, state laws have a

46. 114 U.S. 542 (1885).

47. Id. at 547 .

48. Divine v. Unaka National Bank, 125 Tenn. 98, 140 S.W. 747 (1911).

49. Danielson v. Donmopray, 57 F.2d 565 (D. Wyo. 1932). (1905).

50. McCarthy v. R.G. Packard Co., 105 App. Div. 436, 94 N.Y. Supp. 203

51. United States v. Paul, 6 Pet. 141 (U.S. 1832).

52. Arlington Hotel Co. v. Fant, 278 U.S. 439 (1929).

53. McCarty v. Hollis, 120 F.2d 540 (10th Cir. 1941). 
residency or similar requirement limiting their application to the "county" or "state." 54 Maryland was the first state to hold that a resident of a federal reservation is not a resident of the state so as to be entitled to sue for divorce in the state courts.55 Similar decisions have since been rendered in other states..$^{56}$ As there is no divorce jurisdiction in the federal courts in respect to such areas ${ }^{57}$ the party must either abandon his suit or move to some state and establish a residence for the statutory period.

Maryland has since enacted legislation providing that all persons residing within the physical boundaries of the state but on property over which jurisdiction is exercised by the federal government shall be considered residents of the state for the purposes of jurisdiction of the equity courts in applications for divorce or the annulment of marriage. ${ }^{58}$ Kansas, too, has met the difficulty by similar legislation. Its provision allows one who has been a resident on a federal military reservation within its borders for one year to sue for a divorce in a court of an adjoining county. ${ }^{59}$ The Kansas statute was subsequently upheld by the state court. ${ }^{60}$ Authority for such legislation was based on the assumption that it made no change in the substantive law which was in force at the time of cession; it merely made possible the use of convenient courts for the enforcement of prior existing law. In 1943, Georgia reached the same result by Constitutional amendment which was ratified by the voters. ${ }^{61}$ Aside from these measures the problem in other states remains unsolved.

A similar obstacle exists as regards the right of inhabitants of a federal area to vote. ${ }^{62}$ Since state constitutions limit the franchise to citizens or residents of the state ${ }^{63}$ it has been held that residents of federal reserva-

54. Consider a few of Pennsylvania's requirements as to residence in other contexts. The Pennsylvania Constitution makes residence in the state a prerequisite for voting, PA. CoNsT. Art. VIII, $\S 1$; for holding county office, PA. Const. Art. $\mathrm{XIV}, \S 3$; and provides that the public school system is for children of the Commonwealth, PA. Const. Art. X, \$1. By statute a bona fide residence in the state for one year is necessary for filing a petition for divorce, PA. STAT. ANN. tit. 23, $\$ 16$ (Purdon Supp. 1950), and residence in the state at the time of entering the service is necessary to qualify one for a soldier's bonus, PA. Stat. Ans. tit. 51, $\$ 443-2$ (Purdon Supp. 1951). Marriage licenses and the authority to issue them refer to a county within the state, PA. Stat. ANN. tit. 48, $\$ 1$ (Purdon Supp. 1950). These are typical of the requirements in most states.

55. Lowe v. Lowe, 150 Md. 592, 133 Atl. 729 (1926).

56. Chaney v. Chaney, 53 N.M. 66, 201 P.2d 782 (1949); Dicks v. Dicks, 177 Ga. 379, 170 S.E. 245 (1933).

57. "We disclaim altogether any jurisdiction in the courts of the United States upon the subject of divorce, or for the allowance of alimony... . "Barker v. Barker, 62 U.S. 582, 584 (1858). This is not true of the District of Columbia where jurisdiction over divorce or annulment is in the U.S. District Court for the District of Columbia, D.C. CoDE tit. $16, \S 416(1940)$, nor in the territorial possessions.

58. Mp. Ann. Code Gen. Laws art. 16, §39 (Cum. Supp. 1947).

59. Kan. Gen. Stat. AnN. c. 60, §1502 (1935),

60. Craig v. Craig, 143 Kan. 624, 56 P.2d 464, clarification denied, 144 Kan.

155, 58 P.2d 1101 (1936).

61. Ga. Laws 1943, tit. 1, pp. 68-69.

62. See note 17 supra.

63. E.g., PA. Const. Art. VIII, §1. 
tions cannot qualify as voters. ${ }^{64}$ In Herken $v$. Glynn ${ }^{65}$ suffrage was denied to inmates of a federal soldiers' home. An interesting dissent ${ }^{66}$ made the argument that state residency could be found in the enabling act admitting Kansas to the Union which provided that the "state shall consist of all the territory included within the following boundaries. . : ." The federal home was situated within these boundaries; ipso facto its inhabitants were residents of the state. A different point was raised in Arledge v. Mabry, ${ }^{67}$ which concerned the legality of votes cast on the Los Alamos area in New Mexico. The court held that the people living on that portion of the land over which exclusive jurisdiction was not exercised qualified as voters. However, since their votes had been cast at polling places on the part of the reservation that was under federal jurisdiction, the votes had not been cast in New Mexico as required by the state constitution. ${ }^{68}$

At the present time a petition is before the circuit court of Frederick County, Maryland on behalf of civilian residents at Camp Detrick, Maryland, over which the United States exercises exclusive jurisdiction. The petition seeks a declaratory judgment as to the status of the complainants under Maryland laws. ${ }^{69}$ One of the chief contentions is taxation without representation: ${ }^{70}$ some of the complainants have been denied the right to vote, but have paid (under protest) state income taxes. In addition, clarification of other rights and obligations is being sought. ${ }^{71}$

While the right to vote perhaps is unchallenged in many instances, nevertheless the question is important, for frequently it has been raised in connection with small local elections where the disqualification of a few votes could swing the election. ${ }^{72}$

It is possible, but not probable, that a "void" may result where both federal and state courts could have jurisdiction. Thus in the Tully cases, ${ }^{73}$ each court was so anxious not to usurp the jurisdiction of the other that the lesser evil seemed to be to have the murderer go unpunished. ${ }^{74}$ It seems that this is an almost isolated situation.

An even more technical dispute arises, and is left unanswered, in the case of marriage. No federal law of marriage exists and most states limit

64. McMahon v. Polk, 10 S.D. 296, 73 N.W. 77 (1897) ; In re Town of Highlands, 22 N.Y. Supp. 137 (1892) ; Sinks v. Reese, 19 Ohio St. 306 (1869). But cf. La Duke v. Melin, 43 N.D. 349, 177 N.W. 673 (1920) (validating votes on the ground that the military reservation had been abandoned and therefore the exclusive jurisdiction of the United States had ceased to exist); and Johnson v. Morrill, 20 Ca1.2d 446, 126 P.2d 873 (1942). (allowing registration of voters in federal area on ground that exclusive jurisdiction was never exercised).

65. 151 Kan. 855, 101 P.2d 946 (1940).

66. Id. at 870, $101 \mathrm{P} .2 \mathrm{~d}$ at 956 (dissenting opinion).

67. 52 N.M. 303, 197 P.2d 884 (1948).

68. N.M. Const. Art. VII, §1.

69. No. 17373, Equity, Cir. Ct. Frederick Co., Md. filed July 7, 1952.

70. Baltimore Sun, Aug. 7, 1952.

71. See note 69 supra.

72. See, e.g., Sinks v. Reese, supra note 64.

73. Supra notes 1 and 2.

74. See text at notes 1 and 2 supra. 
the effectiveness of marriage licenses to counties within the state. ${ }^{75}$ Likewise, the authority of a clerk to issue a license is so limited. ${ }^{76}$ The result of an attack on the validity of a marriage performed under a state license but solemnized on a federal reservation is in doubt. Apparently there has been no such determination. ${ }^{77}$ While provisions upholding the validity of a marriage performed in good faith ${ }^{78}$ or the recognition of a common law marriage ${ }^{79}$ may operate to validate such marriages, this is a poor solution to the problem. Although the policy reasons for upholding such marriages are exceptionally strong, (particularly in the light of the large number of marriages that are solemnized on federal reservations), ${ }^{80}$ and courts would strain to uphold them, it would be more desirable to have an applicable statute which would allay the possibility of subsequent attack. This could be done by each state individually 81 or by Congress providing that states have jurisdiction over such areas for the purpose of regulating marriages.

Certainly these problems are of great interest to the resident of a federal area. One may never become involved in a tort or contract action, but may very well want to marry, vote or send one's child to a county school. ${ }^{82}$

75. See, e.g., PA. Stat. Ann. tit. 48, §1 et seq. (Purdon Supp. 1950).

76. Ibid.

77. An action was started to annul a marriage solemnized by a chaplain at the Valley Forge General Hospital under a Chester $\mathrm{Co}$., $\mathrm{Pa}$. marriage license. The theory of the case was lack of authority in the chaplain to perform the marriage under a state license. Campbell v. Smalet, Superior Court of New Jersey, Somerset Co., Chancery Division, Docket \#M-439-51 (1951). Subsequently the action was abandoned in part because of (1) the Pennsylvania law making the child of an annulled marriage a bastard and (2) the probable reluctance of the court to establish a precedent of this kind without a clear statutory mandate, in view of the number of marriages of this type that would be affected and the strong public policy against the dissolution of a marriage. Communication to the University of Pennsylvania Law Review from George G. Mutnick, attorney for the plaintiff, (Mar. 13, 1952) on file Biddle Law Library, University of Pennsylvania Law School.

78. Kentucky has a statutory provision for good faith as follows: "No marriage solemnized before any person professing to have authority therefor shall be invalid for the want of such authority, if it is consummated with the belief of the parties, or either of them, that he had authority and that they have been lawfully married." Kx. REv. STAT. c. 402, \$070 (1942). This has been construed to cover the situation of marriage by a Chaplain on a reservation under federal jurisdiction in the state although technically, since he does not reside in the state, he has no authority to perform such a marriage under state law. (Informal opinion of the Assistant Attorney General of Kentucky, 1944 by Communication to the University of Pennsylvania Law Review from Lt. Col. Ray K. Smathers, Ft. Holabird, Maryland, [Mar. 15, 1952] on file in Biddle Law Library, University of Pennsylvania Law School.) When the marriage ceremony is shown to have been performed there is a strong presumption in favor of the validity of the marriage. Griffith v. Lunney, $300 \mathrm{Ky} .66,187$ S.W.2d 431 (1945).

79. Buradus v. General Cement Products Co., 356 Pa. 349, 52 A.2d 205 (1947).

80. Note the large number of wartime marriages and also, long recognized, the popularity of having marriages performed at Annapolis and West Point. Marriages at the latter Academy are performed under licenses obtained in New York State. There seems to be no statutory provision that covers this situation if West Point is not considered a part of the state. See N.Y. Domestic REtations LAw $\$ 11$ et seq.

81. See text at note 116 et seq. infra. 1841).

82. For discussion of this, see Opinion of the Justices, 1 Metc. 580 (Mass. 


\section{Recognition AND REMEDY}

Federal Actions as to Crimes.-The problems created by the federal areas have not remained unnoticed, although to some extent they have been ignored. The latter can be accounted for in various ways. For one thing, cases raising these problems comprise but a small proportion of total litigation over the country as a whole. Also, for many years such areas existed mainly for military purposes and their inhabitants consisted of a limited number of military personnel governed, in many cases, by army or navy regulations. It is only recently that federal projects have required that a great concentration of civilian employees be domiciled on federal lands for numerous and divergent purposes.

As early as 1825 a federal criminal statute provided that when a crime was committed on a federal area within a state and no punishment was specified such punishment should be fixed according to state laws governing the same crime. ${ }^{83}$ Subsequently, at intervals over the years, various Assimilative Crimes Acts have been passed, each providing that, as to federal reservations, in the absence of a federal crime, the state laws then in force should apply as federal laws. ${ }^{84}$ Conventional holdings that only the laws in force at the time of such enactment are effective ${ }^{85}$ necessitated this periodic adoption to keep abreast of changes in the state criminal laws. Nevertheless, long intervals between adopting statutes have produced great discrepancies between the laws which apply in the states and in the federal areas within them. ${ }^{86}$

The new Criminal Code of the United States ${ }^{87}$ contains a section which provides that:

"Whoever within or upon any of the places now existing or hereafter reserved or acquired as provided in $\S 7$ of this title, ${ }^{88}$ is guilty of any act or omission which, although not made punishable by any enactment of Congress, would be punishable if committed or omitted within the jurisdiction of the State, Territory, Possession or District in which such place is situated, by the laws thereof in force at the time of such act or omission 89 shall be guilty of a like offense and subjected to a like punishment." 90

83. 4 STAT. 115 (1825).

84. The Criminal Statutes were as follows: 14 Stat. 13 (1866); 30 STAT. 717 (1898), 35 Stat. 1145 (1909); 48 STAT. 152 (1933); 49 Stat. 394 (1935); 54 STAT. 234 (1940), 18 U.S.C. \$ 468 (1946), as amended, 62 STAT. 683 (1948), 18 U.S.C. \$ 13 (Supp. 1952).

85. Franklin v. United States, 216 U.S. 559 (1909); United States v. Paul, 6 Pet. 141 (U.S. 1832).

86. There was one forty year period between the first statute aimed at adopting state law, 4 Stat. 115 (1825), and 14 Stat. 13 (1866) which was really the first of the Assimilative Crimes Acts. (However, the Act of 1825 was the basis for these later enactments).

87. 18 U.S.C. (1948).

88. $\$ 7$ refers to jurisdiction on the high seas and also such federal areas as are here under discussion.

89. Italics added.

90. 18 U.S.C. $\$ 13$ (Supp. 1952). 
The italicized provision was specifically put in to cover future changes in state law and render unnecessary periodic pro forma amendments to keep abreast of changes in local law. ${ }^{91}$

The difficulty with this approach is that although the adoption of existing state law is proper ${ }^{82}$ the courts have repeatedly implied that the adoption of prospective state legislation would be open to attack as an unconstitutional delegation of power by Congress to the states. ${ }^{93}$ This defense has been set up frequently in criminal cases arising under the federal statutes. Each time the court has avoided deciding the question by holding that the statute only gave effect to the existing laws of the state; each time the court implied that if the delegation question had been reached it might have been determinative. ${ }^{94}$ While there is no specific decision on delegation in this area there is recent dictum which suggests that the argument has not lost its vitality. ${ }^{95}$ Possibly a court would go out of its way to uphold such legislation in view of its obvious desirability. Such a test is likely to arise in connection with the specific wording of the new Criminal Code, but so far it is unchallenged.

Federal Action in Civit Matters.-Ameliorative legislation outside the criminal field has been of a more limited scope. The most notable progress has come in recent years with the enactment of statutes dealing with specific areas of law. In 1928 Congress provided for the application of state laws in actions for wrongful death or injury occurring within a national park or other area under the exclusive jurisdiction of the federal government. ${ }^{96}$ The right of action for death exists "as though the place were under the jurisdiction of the State within whose boundaries such place may be," ${ }^{97}$ while that for injuries "shall be governed by the laws of the State. . . ." 98 The attempted application of these provisions proved less comprehensive than desired. For example, industrial insurance and

91. 18 U.S.C. $\$ 13$, reviser's note (Supp. 1952).

92. Washington, P. \& O. Ry. v. Magruder, 198 Fed. 218 (D. Md. 1912).

93. The Federal Statute "does not purport to delegate to the state of South Dakota authority at any time in the future to fix, ad libitum, the punishment of federal offenses. This it could not do." Hollister v. United States, 145 Fed. 773, 779 (8th Cir. 1906). To the same effect, Congress "would hardlly be willing beforehand to adopt all the criminal statutes a state might in future enact. A Statute to this effect might be classed as delegating legislative authority, which is not proper." United States v. Barnaby, 51 Fed. 20, 23 (C.C.D. Mont. 1892).

94. Jerome v. United States, 318 U.S. 101 (1943); Washington, P. \& O. Ry. v. Magruder, 198 Fed. 218 (C.C.D. Md. 1912) ; Franklin v. United States, 216 U.S. 559 (1909); Hollister v. United States, 145 Fed. 773 (8th Cir. 1906); United States v. Tucker, 122 Fed. 518 (W.D. Ky. 1903); United States v. Barnaby, 51 Fed. 20 (C.C.D. Mont. 1892).

95. Prudential Insurance Co. v. Benjamin, 328 U.S. 408, 439 (1946) (obviously sidestepping the delegation question in dealing with a provision of the McCarran Act [59 STAT. 33, 34, 15 U.S.C. \$\$ 1011-1015 (1945)] consenting to state regulation of insurance companies).

96. 45 StAT. 54 (1928), 16 U.S.C. $\$ 457$ (1941).

97. Ibid.

98. Ibid. 
workmen's compensation acts were held to be ineffective in federal areas. ${ }^{99}$ The reasoning supporting this conclusion was that the federal statute referred to actions at law while the state workmen's compensation statutes had abolished actions at law for negligence and substituted a whole new system. ${ }^{100}$ On the other hand the 1928 Act has been the authority for the incorporation of a subsequently enacted state guest statute, by interpreting "the laws of the state" to mean existing law as declared from time to time. ${ }^{101}$ Congress has now filled the gap created by these decisions by vesting authority in the states to apply their respective workmen's compensation laws to all lands and buildings owned or held by the United States "in the same way and to the same extent as if said premises were under the exclusive jurisdiction of the State within whose exterior boundaries such place may be." ${ }^{102}$ The law also specifically states that the United States does not relinquish jurisdiction for any purpose over the property named except to the extent enumerated above. While this section was not applicable to causes of action arising before its enactment ${ }^{103}$ it has subsequently rounded out the attempt to place state and federal employees on an equal footing in respect to their rights of recovery. ${ }^{104}$ Thus:

"The effect of this Act is, therefore, to restore the status quo ante, and the purpose was to make sure that employees of contractors during work on a federal building in a federal area would be able to recover compensation benefits for disability or death." 105

The legislation having the greatest scope and effect is that which restored to the states some power of taxation within federal areas. By an Act of Congress in 1940, motor fuel, sales and use, and personal income taxes may be levied in such areas by the states, ${ }^{106}$ thus providing an appreciable increase in revenue. ${ }^{107}$ Such provisions are limited to the extent

99. Martin v. Clinton Construction Co., 41 Cal.App.2d 35, 105 P.2d 1029 (1940) ; Pound v. Goulding, 237 Ala. 387, 187 So. 468 (1939) (the workmen's compensation law did not apply so the old Employers Liability Act remained in force in the area); Utley v. State Industrial Commission, 176 Okla. 255, 55 P.2d 762 (1936); Murray v. Gerrick \& Co., 172 Wash. 365, 20 P.2d 591 (1933), aff'd, 291 U.S. 315 (1934) (holding the Washington Industrial Insurance Act unenforceable).

100. Ibid.

101. Kitchens v. Duffield, 83 Ohio App. 41, 45, 76 N.E.2d 101 (1947).

102. 49 Stat. 1938, 1939 (1936), 40 U.S.C. $\$ 290$ (1946).

103. Employers' Liability Assurance Corp., Ltd. v. DiLeo, 298 Mass. 401, 10 N.E.2d 251 (1937).

104. Capetola v. Barclay White Co., 139 F.2d 556 (3d Cir. 1943) ; Young, Adm'r v. Tarlton, Contractor, Inc., 204 Ark. 283, 162 S.W.2d 477 (1942); Ottinger Bros. v. Clark, 191 Okla. 488, 131 P.2d 94 (1942). All of these cases uphold recovery under state compensation acts.

105. Travelers Insurance Co. v. Cardillo, 141 F.2d 362, 363 (D.C. Cir. 1944).

106. 54 Stat. 1059 (1940), 4 U.S.C. $\S 13$ (1940) as amended, 61 Stat. 641 (1947), 4 U.S.C. $\$ \$ 104-106$ (Supp. 1951).

107. These are among the highest revenue producing taxes levied by the states. See tables Statistical Abstract of the United States 393 (Bur. Census 70th ed. 1949). 
that instrumentalities of the United States are still immune. ${ }^{108}$ This immunity is fortified by statute; ${ }^{109}$ however, national parks are included, ${ }^{110}$ which should provide a substantial basis for additional receipts. ${ }^{111}$ The income tax provision was discussed in Kiker v. City of Philadelphia. ${ }^{112}$ Justice Drew, after calling attention to the great lack of uniformity in the tax field, remarked that:

"For the purpose of correcting these anomalous situations, it seems to us, and to enable State taxation to fall alike upon all who earned income in the state within whose boundaries the reservation was located, and in recognition of the generosity of the states which had granted to the Federal government exclusive jurisdiction over land within their respective territorial limits without reserving the right of taxation Congress, in the best interests of our dual forms of government, enacted Pub. Act No. 819." 113

This thought could as appropriately be applied to the other tax provisions. Another recent provision of general effect is that the United States is no longer required to obtain exclusive jurisdiction over its lands and until notice is filed with the governor of the state it shall be conclusively presumed that no such jurisdiction has been accepted. ${ }^{114}$ This is a reversal of the former policy, and can have the desirable effect of leaving the states with jurisdiction rather than forcing it on the federal government. For while it may seem that exclusive jurisdiction is a logical concomitant of federal ownership and use of land, it is impractical and undesirable from many viewpoints. In most instances the government does not need exclusive jurisdiction to carry on the projects for which the area is acquired. Mere lack of interference by the states with the actual federal functions themselves should be sufficient. Moreover, as seen above, the federal government does not offer the inhabitants of federal areas the advantages of local government. The various federal statutes make it apparent that the attention of Congress has been called to some of the most recurrent problems of the federal areas. But these statutes are only hesitant steps toward the solution of the jurisdictional-geographical dichotomy.

108. This doctrine was first set forth in McCulloch v. Maryland, 4 Wheat. 316 (U.S. 1819).

109. 54 Stat. 1059 (1940), 4 U.S.C. $\$ 13$ (1940), as amended, 61 Stat. 641 (1947), 4 U.S.C. $\$ 107$ (Supp. 1951) (specifically providing for the immunity of instrumentalities of the United States).

110. 38 Ops. Atr'y GeN. 522 (1936).

111. Sales and motor fuel taxes within National Parks would seem to be a lucrative source of revenue in view of the increasing numbers of visitors to such areas. 174 such areas received 24,934,669 visitors in 1948. Statistical Abstract OF THE UNITEd States 164, table 197 (Bur. Census 70th ed. 1949).

112. $346 \mathrm{~Pa}$. 624, 31 A.2d 289 (1943). This case decided that the Philadelphia wage tax applied to workers in federal areas, specifically the Philadelphia Navy Yard.

113. Id. at 636,31 A.2d at 296.

114. Rev. Stat. $\$ 355$, as amended, 40 U.S.C. $\$ 255$ (1940). 
State Action.-There is a dearth of legislation by the states relating to federal areas within their boundaries. As mentioned above, Kansas, Maryland and Georgia have changed their residency requirements for divorce so as to include the residents of federal areas. ${ }^{115}$ In the same vein, in 1951 the Pennsylvania Senate passed a bill which provided that all marriages solemnized by a chaplain on a federal reservation within the borders of the state under a state marriage license be considered of the same validity as those performed within the Commonwealth. It likewise provided for the validity of future marriages by authorizing the issuance of marriage licenses stating that the marriage is to be performed within a federal area. ${ }^{118}$ The bill was referred to the Judiciary Committee of the House of Representatives but was not brought out of Committee before the end of the session. ${ }^{117}$ It is odd that more legislation of this nature has not been passed in view of the various actions which have failed because of some technical state requirement, ${ }^{118}$ and which could be cured by statute or, less readily, constitutional amendment.

A second and increasingly important state solution has been to avoid the problem at the outset by reserving certain powers to the state in the act ceding jurisdiction. The old idea that only the reservation of service of process was compatible with exclusive federal jurisdiction has been modified to a great extent.119 While the first reservations were of jurisdiction over railroad rights of way ${ }^{120}$ or roads and their upkeep, ${ }^{121}$ subsequently such things as voting were included. Tennessee tried to reserve the franchise for inmates of a federal soldiers' home, but the state court held that this was unconstitutional on the ground that residency at the home was not such residence as the state constitution required..$^{122}$ However, since that decision California has reserved the franchise for the inhabitants of Kings Canyon National Park; ${ }^{123}$ and in Johnson v. Morrill ${ }^{124}$ the California court held that residents of land acquired under the Lanham Act, ${ }^{125}$ if otherwise qualified, were entitled to register as voters. The Supreme Court of Kansas reached the same conclusion, ${ }^{128}$ the authority for both decisions being a provision in a federal housing act that the civil rights of the resi-

115. Ga. Laws 1943, tit. 1, pp. 68-69; Kan. Gen. Stat. Ann. c. 60, §1502 (1949) ; Md. Ann. Code Gen. LAws art. 16, §39 (Cum. Supp. 1947).

116. Pa. Sen. Bill No. 846, 139th Sess. (1951).

117. Compronwealth of Pennsylvaita, History of Senate Bills 182 (Last Sess. 1951).

118. See pp. 130-2 supra.

119. See James v. Dravo Contracting Co, 302 U.S. 134 (1937).

120. See Fort Leavenworth R.R. v. Lowe, 114 U.S. 525 (1885).

121. See United States v. Unzeuta, 281 U.S. 138 (1930).

122. State v. Willett, 117 Tenn. 334, 97 S.W. 299 (1906).

123. Cal. Laws 1943 , c. $96, \S 1$

124. 20 Cal.2d 446, 126 P.2d 873 (1942).

125. 54 Stat. 1125 (1940), as amended, 42 U.S.C. $\S \S 1506,1524,1553,1575$, 1575n (Supp. 1949). This Act is concerned with war housing.

126. State v. Corcoran, 155 Kan. 714, 128 P.2d 999 (1942). 
dents of the area would not be denied. ${ }^{127}$ This was interpreted as including voting.

Perhaps a more far-reaching reservation is the right to tax which has been upheld as compatible with federal jurisdiction. ${ }^{128}$ Probably the broadest retention of power is that discussed in James $v$. Dravo Contracting Co. ${ }^{129}$ This is West Virginia's reservation of "such other jurisdiction and authority over the area as is not inconsistent with the jurisdiction ceded to the United States." Under this, a gross receipts tax on businesses carried on within the area solely for the federal government was held valid.

Of course, once the state has ceded jurisdiction over an area it cannot impose additional restrictions, but Congress can recede jurisdiction to the states. ${ }^{130}$ Reservation by the states, plus the fact that exclusive federal jurisdiction is no longer presumed without notice ${ }^{131}$ should enable the states to maintain a greater degree of control over areas ceded in the future.

\section{Evaluation of the Possible Solutions}

Undoubtedly the correction of any problems, no matter how small, is a step in the right direction. However, it would seem that any real solution of the federal area difficulties must be comprehensive in scope. Looking to the states for relief is unsound. While it is possible that those problems which are purely local in origin, as the requirements for divorce and voting ${ }^{132}$ could be solved by state legislation, it is doubtful that this will be done, judging by the paucity of even isolated attempts in the past. Nor would such legislation cover all the areas of dispute.

Frequently it has been suggested that Congress enact a complete body of law for the areas under its jurisdiction. This would be a major task in itself and in reality is probably not necessary. Furthermore, in all probability there would remain a discrepancy between that law and the law of the state so that the federal residents would remain as isolated as ever. Again, judging from past action, Congress is in no hurry so to act. On the other hand, periodic legislation by Congress to adopt state law, runs afoul of obsolescence. Unless there is frequent enactment at short intervals there is bound to be a lag.

The most sensible solution, assuming its constitutionality, is that set forth in the new criminal legislation, ${ }^{133}$ which sanctions the application of both existing and prospective state law. By an Act of Congress generally adopting such state law, either in specified areas or in all fields of law except

127. 54 STAT. 1128 (1940), as amended, 42 U.S.C. $\$ 1547$ (1946).

128. Silas Mason Co. v. Tax Commission of Washington, 302 U.S. 186 (1937) (gross receipts tax on receipts of contractors working for the government at Grand Coulee Dam).

129. 302 U.S. 134 (1937).

130. 49 StaT. 1938, 1939 (1936), 40 U.S.C. $\$ 290$ (1946).

131. See note 114 supra.

132. See e.g., note 54 supra.

133. 18 U.S.C. $\$ 13$ (1948) (providing for the application of state laws in force at the time the act is committed). 
certain ones, the problems largely could be solved. An equally sound solution might be recession of jurisdiction by the United States to the states except such as is absolutely necessary for carrying on the actual federal functions.

As to lands to be acquired in the future, it is doubtful whether there is need or justification for the federal government to take exclusive jurisdiction. ${ }^{134}$ The jealousy of the original states and the necessity of having exclusive jurisdiction to insure the unhampered use of federal areas for defense purposes ${ }^{135}$ have disappeared. The states could reserve at the outset all powers except those required to attain the purposes for which the land is procured, the determination of which could be handled by the courts.

Thus it seems that the problem is not without solution. All of these devices have been tried sporadically. There remains the task of stimulating further accomplishment along these lines.

134. See Rev. Stat. $\$ 355$, as amended, 40 U.S.C. $\$ 255$ (1940).

135. The Federalist No. 43 at 279, 280 (Mod. Lib. ed. 1943); Patterson, The Relation of the Federal Government to the Territories and the States in Landholding, 28 TEXAS L. Rev. 43, 57-62 (1949). 